\title{
Jilbab dan Identitas Sosial: Relasi Keberagamaan dan Status Sosial Perempuan Berjilbab di Ponorogo
}

\author{
Unun Roudlotul Janah ${ }^{1^{*}}$, Shofwatul Aini ${ }^{2}$ \\ 1, 2 Institut Agama Islam Negeri Ponorogo, Ponorogo, Indonesia \\ *ununrj@yahoo.com
}

\begin{abstract}
Abstrak
Pemakaian jilbab tidak hanya sebagai identitas keagamaan, tetapi juga berfungsi sebagai pernyataan atas nilai atau status sosial seseorang yang memiliki dua sisi yaitu pertama, bersifat tetap (ascribed), kedua, bisa diubah (achieved). Fokus artikel ini adalah untuk mengetahui bagaimana gambaran identitas sosial bagi perempuan berjilbab di Ponorogo dan konsekuensinya. Hasil analisis data menggunakan teori interaksionalisme simbolik menunjukkan beberapa temuan pertama, pola kehidupan keberagamaan (religiusitas) perempuan bercadar dan berjilbab syar'i cenderung mengarah pada eksklusivisme beragama. Sementara perempuan berjilbab sedang cenderung mengarah pada tipologi beragama yang inklusif-pluralis. Kedua, Bagi perempuan bercadar dan berjilbab syar'i, jilbab adalah identitas sosial yang dimensinya dibentuk oleh norma dan nilai-nilai agama "yang paling benar" yang harus ditaati dan dijalankan dalam komunitasnya. Sedangkan bagi perempuan berjilbab sedang, jilbab adalah identitas sosial didasari oleh norma agama tanpa harus menafikan kebenaran ajaran agama yang dimiliki oleh kelompok lain dalam kontek relasi sosial dan hubungan kemasyarakatan.
\end{abstract}

Kata Kunci : Identitas sosial, religuisitas, status sosial, eksklusivisme 


\begin{abstract}
The use of headscarves is not only religious identity but also functions as a statement of the value or social status of a person who has two sides, first, ascribed, second, and can be achieved. The focus of this article is to find out how the description of social identity for veiled women in Ponorogo and its consequences. The results of data analysis using symbolic interactionalism theory show some of the first findings, the pattern of life of religiosity (religiosity) of veiled women and veiled Shar' i tends to lead to religious exclusivism. While medium veiled women tend to lead to pluralist religious inclusive typologies. Second, for veiled and veiled Shar' i women, headscarves are social identities whose dimensions are shaped by "the trust" religious norms and values that must be adhered to and carried out in their community. While for medium veiled women, headscarves are social identities based on religious norms without having to deny the truth of religious teachings held by other groups in the context of social relations and community relations.
\end{abstract}

Keywords: Religiosity, social identity, social status, exclusivism

\title{
Pendahuluan
}

Jilbab pada masa awal Islam merupakan simbol atau lambang ketaatan seorang muslimah. Jilbab dianggap sebagai identitas seorang muslimah, namun pada masa belakangan ini, banyak muslimah berjilbab tetapi melupakan fungsi jilbab yang sesungguhnya menurut agama. Penggunaan jilbab hanya sekedar untuk mengikuti trend and mode (Suhendra, 2013, hal. 17). Hal ini dibuktikan dengan kajian tentang motif para muslimah dalam memakai jilbab. Secara umum motif pemakaian jilbab adalah motif teologis, motif psikologis, dan motif modis atau tuntutan gaya hidup (lifestyle) (Ahmadi \& Yohana, 2017; Farihah, 2018). Ada juga yang menambahkan penggunaan jilbab atas motif paksaan (Yulikhah, 2016, hal. 103), dan juga motif politis (Setiawan, 2016, hal. 109).

Ada empat motif penggunaan jilbab yaitu pertama, jilbab dianggap bagian dari simbol modernitas yang ditujukan untuk memenuhi tuntutan gaya hidup. Mereka tidak lagi memperhatikan apakah bentuk jilbab mereka masih termasuk dalam tuntunan agama atau tidak (Budiati, 2011). Kedua, berasal dari faktor internal yaitu dari diri sendiri berupa adanya kesadaran untuk memakai jilbab. Ketiga, faktor eksternal yaitu adanya motivasi dari orang lain, adanya aturan, dan pengaruh lingkungan (T. Rahayu \& Fathonah, 2016, hal. 273-274). Keempat, motif kelabilan psikologi yang dapat 
ditunjukkan dengan adanya fenomena memakai jilbab tetapi kemudian melepasnya. Seperti yang terjadi sekitar tahun 2006, dua artis yang melepas jilbabnya yaitu Tri Utami dan Tya Subiakto (Juneman, 2010, hal. 1) dan pada akhir-akhir ini, fenomena melepas jilbab terulang kembali seperti yang dilakukan artis Rina Nose dan Nikita Mirzani. Hal tersebut tidak terlepas dari faktor yang mempengaruhi masing-masing pengguna jilbab, diantaranya faktor lingkungan, faktor ekonomi, dan faktor budaya (Wahyuningsih, 2017).

Jilbab seharusnya diartikan sebagai bentuk ketaatan terhadap agama dan sebagai bentuk ekspresi dan komitmen keberagamaan mereka dalam konteks kehidupan seharihari (Pakuna, 2014). Meskipun demikian, jilbab sebenarnya bukan hanya berfungsi sekedar perlindungan, kesopanan dan penyembunyian, serta kondisi magis-religius (Suhendra, 2013). Lebih dari itu pemakaian jilbab memiliki fungsi-fungsi lain diantaranya yaitu ekspresi individualistik, nilai atau status sosial, definisi peran sosial, nilai atau status ekonomi, dan simbol politis (Barnard, 2011, hal. 69-100).

Pemakaian jilbab juga dapat berfungsi sebagai pernyataan atas nilai atau status sosial. Hal yang cukup signifikan dalam kaitannya dengan kajian ini adalah bahwa nilai atau status sosial seseorang memiliki dua sisi yaitu pertama, nilai atau status sosial yang bersifat tetap (ascribed), yaitu nilai atau status sosial yang diperoleh dan bersifat "warisan" atau turun temurun. Kedua, nilai atau sosial yang bersifat bisa diubah (achieved) (Barnard, 2011) yaitu nilai atau status sosial yang dilahirkan dari "hasil usaha" seseorang dengan berbagai atribut (termasuk pakaian dan jilbab) atau prestasi yang dimilikinya. Memahami hal demikian banyak para pengkaji berkesimpulan bahwa memakai jilbab juga dapat dimaknai sebagai pernyataan atas nilai atau status sosial dari orang yang memakainya bukan berdasarkan pada ketetapan hukum yang mewajibkan (Thohari, 2011). Oleh karena itu, pemakaian jilbab pada masa sekarang ini membuat orang yang melihatnya bisa mengetahui status sosial seseorang hanya dengan melihat model baju dan jilbab yang digunakannya.

Nilai atau status sosial pada akhirnya akan mempengaruhi peran sosial seseorang (Bodovski, 2010). Hal ini disebabkan adanya ekspektasi yang mengitari nilai atau status sosial (Fitriyah, 2018). Ekspektasi tersebut mendefinisikan atau 
mengekspresikan bagaimana individu-individu yang menempati posisi status untuk berperilaku, dan mungkin diacukan sebagai peran. Dengan demikian, peran sosial seseorang diproduksi oleh statusnya dan mengacu pada sejumlah ekspektasi yang dapat dilakukannya (Barnard, 2011). Perempuan yang memakai jilbab memiliki nilai atau status sosial yang kemudian mengarahkannya untuk melakukan hal-hal tertentu sebagai perwujudan peran sosial yang harus dimainkannya.

Pemakaian jilbab tidak harus dilihat dari kaca mata agama semata, akan tetapi juga dapat dilihat melalui status sosial pemakainya. Sehingga penafsiran ulang terhadap jilbab ini tentu saja melibatkan banyak hal yaitu persepsi, makna, motif, dan pesan yang ingin disampaikan melalui jilbab. Aspek individual yang dimiliki oleh pemakai jilbab (aspek internal) yang dalam bahasa kaum interaksionisme-simbolis dikenal dengan istilah fakta subyektif tersebut juga terkait dengan aspek eksternal yang berupa kultur budaya masyarakat -fakta obyektif- tempat pemakai jilbab tersebut berada. Kedua aspek internal (subyektif) dan eksternal (obyektif) tersebut membentuk relasi sirkular yang saling mempengaruhi diantara keduanya. Persepsi, makna, dan motif individu (subyektif) pemakai jilbab mempengaruhi terbentuknya kultur budaya tertentu di tengah masyarakatnya, demikian pula sebaliknya kultur budaya masyarakat sangat berpengaruh terhadap pembentukan persepsi, makna, dan motif pemakainya.

Fokus kajian ini adalah mengurai dan menganalisis pola-pola kehidupan keberagamaan perempuan berjilbab di Ponorogo dan menitikberatkan pada dua fenomena yang saling terkait. Pertama, Ponorogo diketahui sebagai komunitas kaum santri yang patuh terhadap ajaran Islam dan memiliki banyak pondok pesantren baik yang bercorak modern atau tradisional (salaf). Hal ini ditunjukkan oleh banyaknya jumlah pesantren yang ada di Ponorogo yang mencapai angka 94, meliputi pondok pesantren modern, salaf, mu'adalah, tahfidzul Quran, dan campuran.

Kedua, cara berpakaian (memakai jilbab) masyarakat Ponorogo dikenal karena dasar kebajikan agama yang dipegangi. Berdasarkan hal tersebut, maka kajian ini menguji motivasi dasar dari perempuan berjilbab dan kemudian menganalisisnya dengan mencari hubungan antara komitmen keberagamaan dan identitas sosial bagi perempuan berjilbab dan membatasi pada perempuan dengan tiga kategori model 
jilbab, yaitu jilbab cadar, jilbaber (jilbab syar'i), dan jilbab tradisi, dengan empat kategori profesi yaitu pendidik (guru dan dosen), pelajar (santri atau mahasiswi), pebisnis, dan ibu rumah tangga. Pendidik adalah profesi pertama yang dipilih karena paling tidak mewakili profesi yang sering diisi oleh perempuan dan kebanyakan mereka dalam melaksanakan tugasnya menggunakan busana Muslim. Profesi berikutnya yaitu pelajar, termasuk santri dan mahasiswi dan untuk melengkapi kategori yang lain, diambil kategori ibu rumah tangga sebagai perwakilan perempuan yang lebih memilih untuk berada di rumah dibandingkan wanita yang berkarier, dan juga perempuan pebisnis sebagai representasi perempuan yang memilih untuk berwirausaha. Dengan adanya informan yang bervariasi tersebut diharapkan dapat diperoleh kesimpulan yang proporsional.

Kajian ini difokuskan untuk menemukan jawaban atas identitas sosial bagi perempuan berjilbab dibalik bentuk jilbab yang mereka pilih, juga konsekuensi yang kemudian muncul akan pilihan tersebut. Pertanyaan pertama, bagaimana pola kehidupan keberagamaan perempuan berjilbab di Ponorogo. Pertanyaan ini menjadi penting karena bicara identitas sosial dibalik jilbab yang mereka kenakan memerlukan premis nilai tertentu sebagai standar pengetahuan akan wacana jilbab yang berkembang saat ini dan pola keberagamaan yang dijalani sebagai konsekuensinya. Selanjutnya pertanyaan kedua adalah tentang bagaimana cara mereka menghubungkan antara pemakaian jilbab dengan status sosial di tengah masyarakat? Pertanyaan ini merupakan pertanyaan pokok dalam artikel ini untuk mengungkap identitas sosial sesuai dengan model keberjilbaban yang mereka pilih.

\section{Metode}

Artikel ini menggunakan pendekatan emik atau perspektif insider. Dalam hal ini, untuk mancari pemaknaan atas pemakaian jilbab serta relasinya dengan identitas sosial bersumber pada ungkapan-ungkapan yang diutarakan oleh perempuan sendiri melalui sebuah pertanyaan adakah pemakaian jilbab berhubungan erat dengan keinginan menyatakan status sosial melalui simbol jilbab. Adapun informan yang berjilbab dibatasi pada empat kategori yaitu: pendidik (guru dan dosen), pelajar (santri dan mahasiswi), pebisnis, dan ibu rumah tangga. Wawancara dilakukan pada 11 perempuan berjilbab dari empat kategori tersebut dengan tiga pilihan model jilbab, yaitu jilbab 
cadar, jibab syar'i, dan jilbab tradisi untuk menemukan persepsi mereka tentang status sosial dan relevansinya dengan jilbab yang mereka kenakan.

Pengumpulan data yang digunakan adalah perpaduan antara observasi dan wawancara mendalam. Observasi dilakukan untuk memperoleh gambaran tentang polapola keberagamaan perempuan berjilbab di Ponorogo. Dengan pengamatan, melihat lebih dekat dalam batas-batas tertentu dan mengalami situasi yang terjadi pada komunitas yang diteliti, seperti ikut dalam beberapa kegiatan keagamaan, terlibat dalam kesaharian ketika berada dalam tempat tinggal mereka dan di ruang publik. Sementara wawancara mendalam dilakukan untuk mengungkap lebih jauh tentang cara menyatakan status sosial melalui simbol jilbab baik di kalangan pendidik, pelajar, pebisnis maupun ibu rumah tangga. Sedangkan analisis data digunakan model Miles Huberman melalui langkah-langkah reduksi data, penyajian dan verifikasi sampai pada penarikan kesimpulan.

\section{Jilbab dan Interaksionisme Simbolik}

Beragamnya fenomena pemakaian jilbab akhir-akhir ini menjadikan jilbab sebagai kajian Islam kontemporer yang menarik untuk diperbincangkan. Kajian terhadap fenomena jilbab sejatinya merupakan upaya memahami kenyataan sosial yang selama ini acapkali dilihat sebagai sesuatu yang lumrah, tidak berubah, dan tidak terkait apapun selain dari simbol sikap keberagamaan pemakainya. Sebagaimana sudah disinggung di bagian awal bahwa jilbab pada dasarnya adalah simbol dan identitas seorang muslimah. Oleh karena itu, kajian ini mendekati fenomena jilbab dalam kaitannya dengan status sosial tertentu dengan menggunakan teori interaksionisme simbolik untuk mengungkap makna sosial jilbab.

Interaksionisme simbolik didasari oleh proposisi dasar yang menyatakan bahwa perilaku dan interaksi manusia dapat dibedakan karena ditampilkan lewat simbol dan maknanya. Mencari makna dibalik yang sensual menjadi sesuatu yang sangat penting (Basrowi \& Soenyono, 2004, hal. 100). Simbol memungkinkan orang untuk menghadapi dunia material dan dunia sosial dengan membiarkan mereka untuk menyatakan, menggolongkan, dan mengingat obyek yang dijumpai. Simbol juga dapat meningkatkan kemampuan manusia dalam memahami lingkungan dan meningkatkan kemampuan untuk berpikir (Ritzer \& Goodman, 2004b, hal. 292). 
Manusia berelasi dengan sesamanya maupun benda-benda dalam rangka membagi makna. Dengan kata lain tindakan dipahami melalui cara orang menciptakan dan mempergunakan makna-makna daripada sebagai sebuah petunjuk, norma, dan nilai-nilai kultural yang menyediakan penjelasan-penjelasan (atas makna tindakan) tersebut (Blumer, 1969, hal. 59). Beberapa asumsi umum yang digunakan dalam interaksionisme simbolik sebagaimana dikemukakan oleh Ritzer (Ritzer \& Goodman, 2004b) adalah Pertama, manusia hidup dalam suatu lingkungan simbol-simbol yang dapat divisualisasikan. Interaksionisme-simbolis dilakukan dengan menggunakan bahasa (Poloma, 2010, hal. 257-258) dan isyarat. Pakaian yang dipakai seseorang, termasuk jilbab sebagai salah satu pakaian yang acapkali disimbolkan pada diri seorang muslimah. Jilbab sebagai pakaian seorang wanita dapat memiliki makna beragam dari ekspresi kesadaran keberagamaan sampai pada tuntutan dunia mode yang harus diikuti (Shihab, 2004, hal. 2). Jilbab yang dipakai wanita muslimah, dalam pandangan ulama klasik merupakan "kewajiban" agama. Penggunaan jilbab atas dasar magis-religius (sisi normatif) ini didasarkan pada konsep aurat yang seringkali diartikan sama dengan "su'ah" sesuatu yang buruk dan karenanya harus ditutupi (Shihab, 2004)

Jilbab, selain menjadi simbol ketaatan wanita terhadap agamanya. Bagi kelompok wanita lainnya dalam komunitas yang hanya menjadi simbol kesopanan tidak lebih dari itu, hal ini karena bagi mereka, berjilbab atau perintah menutup aurat di hadapan publik dengan cara memakai jilbab bahkan cadar bukanlah perintah ritual keagamaan, bukan ibadah mahdlah atau dalam bahasa hukum yang lain disebut sebagai aspek haji atau bahkan dlaruri, melainkan aspek tahsini. Aspek ini dapat diartikan sebagai aksesori yang berarti bahwa perintah tersebut terkait dengan kesopanan sosial, sebagai simbol moralitas pemakainya.

Kedua, melalui simbol-simbol manusia berkemampuan menstimulir orang lain dengan cara-cara yang berbeda dari stimulan yang diterimanya dari orang lain. Simbol jilbab dalam beragam makna yang dikandungnya, dari sisi sosio-historis, merupakan stimuli bagi masyarakat sekitarnya, dalam rentang waktu dan tempat tertentu masyarakat merespon dan memaknai simbol jilbab sebagai simbol yang berbeda dengan ketika pertama kali dipakai. Perubahan komunikasi simbolis dalam masyarakat tersebut dan mungkin masyarakat sesudahnya terjadi karena adanya -dalam bahasa pengikut 
interaksionisme-simbolis- proses internalisasi yang tidak pernah lengkap dan tuntas, sehingga makna dan simbol menjadi bergeser dan berubah dan menjadi realitas obyektif tempat individu melakukan eksternalisasi yang kembali menjadi stimuli bagi individu dalam masyarakat atau realitas obyektif dalam kurun waktu yang berbeda.

Ketiga, karena simbol adalah bagian sentral dari kehidupan manusia dan dapat dipelajari, maka simbol-simbol itu bisa digunakan untuk memahami tindakan orang lain. Simbol yang diwakili oleh bahasa, isyarat, atau bahkan benda atau entitas simbolis dapat dipelajari dan digunakan untuk memahami tindakan individu karena hal itu menjadi semacam "konvensi". Beragam entitas "benda", pakaian termasuk jilbab, juga dapat menjadi simbol. Entitas ini (baca: jilbab) dapat jadi simbol pelaku yang memakainya, perilaku pemakainya, atau model jilbab dengan status sosial yang ingin ditunjukkannya.

Keempat, dengan mempelajari kultur atau sub kultur, manusia memprediksi tindakan antar sesamanya. Masyarakat melalui kulturnya menyediakan seperangkat arti yang sama terhadap simbol-simbol tertentu. Kultur atau sub kultur masyarakat tertentu, termasuk Ponorogo, merupakan realitas obyektif yang dibentuk oleh perilaku individu melalui eksternalisasi masyarakatnya, melalui objektifikasi, internalisasi, dan eksternalisasi yang saling berkelindan antara kultur feodal, masyarakat "urban", kaum santri yang berada di sejumlah wilayah Ponorogo dan membentuk beragam makna keberagamaan yang disimbolkan melalui jilbab; Ia jadi simbol normatifitas keberagamaan seseorang, jadi simbol moralitas perempuan pemakainya, atau jadi simbol modernitas keberagamaan melalui gaya modis yang dilekatkan padanya beserta beragam makna perifer masing-masing makna.

Kelima, Individu menentukan sendiri entitas benda yang bermakna bagi dirinya. Manusia mempunyai kepribadian sendiri dan mempunyai kemampuan menciptakan sasaran tindakan-tindakannya sendiri. Obyektifikasi individu, dalam berbusana dan berjilbab, tidak secara utuh diserap melalui proses internalisasi, selalu ada yang tersisa, dan bahkan secara subyektif, individu masyarakat terkait dalam hal ini masyarakat perempuan Ponorogo dengan perangkat pengetahuan agama, sosial, moral dan 
kapasitas intelektual lainnya serta budaya pop yang mereka saksikan menjadi bahan pertimbangan model jilbab dan tindakan mereka.

Keenam, berpikir merupakan suatu proses pencarian kemungkinan yang bersifat simbolis dan untuk mempelajari tindakan-tindakan yang akan datang, menaksir keuntungan dan kerugian relatif menurut penilaian individual, di mana satu diantaranya dipilih untuk dilakukan. Pemaknaan jilbab sebagai simbol bagi diri perempuan pemakainya, merupakan penafsiran simbolis. Karena proses penafsiran, kelompok individu perempuan ini khususnya di wilayah Ponorogo melakukan tafsir normatif dengan mempertimbangkan bahwa memakai jilbab berarti kewajiban pribadi sekaligus berdakwah dan keuntungannya adalah pahala dan surga, dan karenanya mereka memilih jilbab dalam pengertian tidak mempertontonkan tubuh di depan publik (Mahmud, 1995, hal. 17). Kelompok individu yang lain menafsiri dengan cara yang lain lagi.

Terkait dengan teori di atas, jilbab adalah simbol yang memiliki makna, sementara memakai jilbab adalah tindakan individu yang terkait erat dengan kultur atau sub kultur masyarakat. Tindakan memakai jilbab adalah pilihan seseorang dengan mempertimbangkan keuntungan dan kerugian terkait tindakan yang akan datang. Memakai jilbab juga bisa dimaknai sebagai stimulus yang diterima seseorang dari sub kultur tertentu, atau bahkan bisa jadi merupakan pilihan tindakan untuk menstimulir orang lain untuk menciptakan sub kultur lain. Dengan kata lain, berjilbab tidak hanya bisa dipahami sebagai tindakan atas dasar pemahaman pemakainya terhadap makna jilbab (motif keberagamaan), lebih dari itu berjilbab juga bisa dipahami sebagai tindakan yang terkait dengan pembentukan kultur atau sub kultur sosial di tempat pemakai jilbab itu berada.

\section{Pola Religiusitas Perempuan Berjilbab di Ponorogo}

Sebelum mengetahui pola kehidupan keberagamaan perempuan berjilbab, perlu dideskripsikan terlebih dahulu tentang landasan pilihan model jilbab untuk melihat adakah pilihan tersebut dilatarbelakangi oleh pemahaman mereka terhadap agamanya ataukah karena faktor lain seperti mengikuti trend mode yang berkembang saat ini, atau karena lingkungan di mana ia tinggal. 
Data perempuan berjilbab di Ponorogo diperoleh dari pendidik, ibu rumah tangga dan wirausahawan serta mahasiswa dan pelajar dari tiga kategori yaitu perempuan bercadar, berjilbab syar'i (jilbaber), dan berjilbab sedang. Secara umum, mereka mengenakan jilbab tidak hanya dipengaruhi oleh salah satu faktor perilaku keberagamaan. Rata-rata semua kategori perempuan berjilbab menunjukkan perilaku keberagamaannya dengan dipengaruhi oleh banyak faktor (multi faktor), yaitu faktor moral dan faktor sosial. Namun kedua faktor tersebut memiliki intensitas dan daya pengaruh yang berbeda untuk masing-masing kategori perempuan berjilbab. Faktor moral yang mendorong pemakaian jilbab adalah pandangan para responden terhadap realitas sosial yang bagi mereka menunjukkan adanya konflik moral berupa berbagai respon atas kewajiban agama yang memerintahkan perempuan untuk menutup auratnya di muka umum. Bagi mereka, berjilbab adalah kewajiban agama, dan meninggalkan jilbab adalah perbuatan tercela secara moral. Namun demikian, walaupun sama-sama menganggap berjilbab adalah kewajiban moral bagi setiap muslimah, namun tiga kategori perempuan berjilbab tersebut berbeda dalam hal intensitas kewajiban yang harus dijalaninya.

Kasus perempuan bercadar, kewajiban (berjilbab) adalah sesuatu yang tidak bisa ditawar lagi. Baginya semua yang terkait dengan perintah Allah harus ditaati baik berupa perintah maupun larangan dan bukan untuk dipilih. Jika ada interpretasi lain tentang kewajiban itu (termasuk menutup seluruh tubuh kecuali mata), maka hal tersebut bisa dianggap sebagai sebuah kesalahan. Sementara perempuan berjilbab syar'i memakai jilbab tidak lain merupakan proses transformasi keberagamaan. Berjilbab syar'i baginya merupakan upaya untuk meninggalkan kondisi masa lalu yang menurutnya tidak baik, menuju kondisi keberagamaan yang lebih baik (hijrah). Namun demikian, kewajiban moral agama untuk menutup aurat tidak serta merta meninggalkan kebutuhan akan rasa nyaman dan mempersempit ruang gerak usaha yang bernilai ekonomis. Sampai pada tahap ini, menjalankan kewajiban menutup aurat bukanlah kewajiban moral agama yang "tidak bisa ditawar lagi" sebagaimana yang diyakini oleh perempuan bercadar.

Berbeda dengan dua kategori perempuan berjilbab di atas, perempuan berjilbab sedang memakai jilbab sebagai suatu tindakan sosial yang tidak semata-mata 
menjalankan kewajiban moral agama tetapi juga mengandung unsur menjaga relasi sosial yang bertumpu pada ajaran sopan santun dalam bermasyarakat. Oleh karena itu, bagi mereka yang berjilbab selain memperhatikan batasan menutup aurat juga harus memperhatikan batasan sopan santun, kerapihan, dan menghindari tindakan berlebihan.

Menyikapi fakta seperti itu, maka perlu untuk memberi analisis lanjutan sebelum menempatkan para perempuan berjilbab dalam sebuah tipologi keberagamaan. Ada beberapa kriteria religiusitas yang dapat digunakan untuk membaca ulang faktafakta perempuan berjilbab di Ponorogo. Setidaknya ada empat kriteria orang yang dianggap mampu menerapkan aspek religiusitas (Wahib, 2015, hal. 112). Keempat aspek tersebut adalah; 1) Kemampuan melakukan differensiasi. 2) Berkarakter dinamis. 3) Integral. 4) Sikap berimbang antara kesenangan dunia tanpa melupakan akhirat.

Dalam hal kemampuan melakukan differensiasi, perempuan berjilbab sedang terlihat lebih menonjol dibandingkan dua kategori perempuan berjilbab lainnya, dapat dilihat dari bagaimana mereka menyikapi kewajiban memakai jilbab yang tidak hanya memperhatikan aspek kewajiban agama tetapi juga mempertimbangkan aspek sosial yaitu kerapihan, kesopanan, dan menghindari sikap berlebihan. Sampai pada tahap ini, perempuan berjilbab sedang memaknai berjilbab bukan semata-mata hubungan vertikal individu yang bersangkutan dengan Tuhan, tetapi juga menyangkut hubungan horizontal dengan sesamanya dalam kontek sosial yang lebih kompleks. Sementara perempuan berjilbab syar'i walaupun tidak berada pada tingkatan yang sama dengan perempuan berjilbab sedang dalam hal differensiasi, tapi setidaknya mereka mulai mempertimbangkan aspek kenyamanan dan aspek ekonomi dalam memberikan makna berjilbab selain sebagai kewajiban agama. Hanya perempuan bercadar yang terlihat kesulitan melakukan differensiasi karena bagi mereka, berjilbab dan bercadar sematamata menjalankan kewajiban agama yang tak bisa dicampuri oleh persoalan di luarnya.

Kondisi sebaliknya justru terjadi pada kriteria kedua yaitu memiliki karakter dinamis. Jika karakter dinamis ini dimaknai sebagai kemampuan mengarahkan motifmotif untuk kepentingan agama, maka perempuan bercadar layak ditempatkan pada 
posisi yang lebih tinggi dibanding dua kategori perempuan berjilbab lainnya. Sementara perempuan berjilbab sedang justru bisa dianggap paling tidak memiliki kriteria ini.

Kriteria lain dari religiusitas adalah kemampuan untuk mengintegrasikan segala aspek kehidupan, termasuk aspek sosial dan ekonomi, ke dalam sikap religiusitasnya. Aspek ini tentu saja erat kaitannya dengan aspek yang pertama (differensiasi). Oleh karena itu, kategori perempuan bercadar mengalami kesulitan untuk melakukan integrasi antara kehidupan keberagamaan dengan aspek lain dalam kehidupannya. Sementara perempuan berjilbab sedang, dengan kemampuan differensiasinya, memiliki kesempatan lebih baik untuk mengintegrasikan sikap keberagamaannya dengan berbagai aspek kehidupan.

Kriteria terakhir yang perlu dicermati adalah kemampuan menyeimbangkan kehidupan dunia dan akhirat. Memakai jilbab dalam konteks ini tidak semata-mata menjadi bentuk pengabdian kepada Tuhan tetapi bisa juga dijadikan sebagai alat untuk memperoleh kehidupan sosial yang lebih baik. Kemampuan untuk menyeimbangkan dua kondisi ini lebih mudah dimiliki oleh perempuan berjilbab sedang dan berjilbab syar'i ketimbang perempuan bercadar. Perempuan berjilbab syar'i sudah berpikir tentang jilbab sebagai salah satu sumber perekonomian. Sementara perempuan berjilbab sedang menjadikan jilbab sebagai modal sosial yang cukup berharga.

\section{Identitas Sosial Bagi Perempuan Berjilbab Di Ponorogo}

Mengeksplorasi status sosial perempuan berjilbab tidak harus dilihat dari kacamata agama semata, akan tetapi juga melalui status sosial pemakainya. Tentu saja penafsiran ini melibatkan banyak hal yaitu persepsi, makna, dan motif serta pesan yang ingin disampaikan melalui jilbab. Memakai jilbab bagi perempuan muslimah tidak semata-semata untuk menutup aurat tetapi dikaitkan dengan kontek sosial yang melingkupinya. Latar belakang pemahaman terhadap teks agama menjadi pijakan bagi perempuan berjilbab di Ponorogo dalam menunjukkan statusnya. Walaupun perlu dicatat di bahwa pemaknaan status sosial tetap menampilkan varian yang berbeda. Keinginan perempuan bercadar untuk menjadi muslimah lebih baik, bahkan mungkin yang terbaik, secara implisit menunjukkan sebuah tuntutan atas hak istimewa dalam hubungan martabat sosial di antara sesama muslimah. Dengan gaya hidup yang spesifik 
(bercadar), dia ingin menunjukkan suatu kondisi yang menurutnya mendukung untuk menempati status sosial tertentu (muslimah yang lebih baik). Tuntutan seperti itu menjadi biasa dalam kajian sosiologis, karena status sosial pada akhirnya akan mempengaruhi stratifikasi sosial seseorang sebagaimana yang diyakini oleh sosiolog Max Weber (Ritzer \& Goodman, 2004a, hal. 138-139).

Terkait dengan pilihan model gamis, jilbab, dan cadarnya, perempuan bercadar lebih suka memilih warna-warna gelap seperti hitam, merah tua, biru dongker, atau coklat. Karena warna-warna gelap ini yang dianjurkan. Sehingga warna-warna terang atau gamis yang bermotif tidak disukainya meskipun bagi muslimah lain terlihat fashionable. Pemilihan model dan warna cadar dan gamis seperti ini dapat dipahami sebagai penegasan identitas diri yang mempengaruhi status sosial. Tindakan tersebut lebih mengarah pada upaya pembentukan sub kultur yang "berbeda" dari kultur kehidupan muslimah di Ponorogo yang mayoritas tidak bercadar. Upaya membentuk sub kultur semacam ini, dalam teori interaksionisme simbolik, dilakukan untuk untuk memperoleh pemaknaan yang sama atas sebuah simbol (jilbab). Dalam hal ini responden menghendaki adanya penerimaan dari orang lain atas makna yang sama bahwa bercadar adalah perilaku yang lebih baik untuk dilakukan oleh kaum muslimah. Jika pemaknaan ini disepakati dan diikuti secara sosial, maka gaya pakaian bercadar akan menjadi sub kultur yang eksistensinya diakui di tengah-tengah kultur busana muslimah Ponorogo pada umumnya.

Perempuan bercadar lain berkeinginan untuk menunjukkan bahwa meskipun bercadar maka harus tetap menjaga penampilannya dalam berbusana dengan pilihan bahan yang berkualitas dengan harga yang mahal untuk dijadikan simbol status sosialnya. Hal ini tidak mengherankan karena sebagaimana diungkapkan oleh Daryanto dan Nugroho, salah satu ukuran yang biasa dipakai untuk menggolongkan status sosial masyarakat adalah standar material (kekayaan) yang dimiliki seseorang (Haryanto \& Nugroho, 2011, hal. 233). Dengan memilih bahan-bahan yang berkualitas dan mahal, maka penegasan status sosial lebih mudah diterima oleh orang lain.

Sedangkan bagi perempuan berjilbab syar'i, meskipun sekilas tidak jauh berbeda dengan kelompok perempuan sebelumnya, artikel ini menganggap perlu memisahkan 
keduanya dalam kategori yang berbeda. Jika masing-masing kelompok perempuan ini berhasil membentuk sebuah sub-kultur yang dibangun oleh keduanya tentu akan berbeda pula. Motif memakai jilbab bagi perempuan pada kategori ini tidak jauh berbeda dengan perempuan berjilbab yang memakai cadar. Keduanya menganggap agama sebagai salah satu bahan pertimbangan memakai jilbab. Baginya, jilbab merupakan kewajiban dalam agamanya, meskipun model yang digunakan beragam dari yang bergaya lokal maupun global (L. M. Rahayu, 2016). Sehingga jilbab bisa menjadi identitas bagi seorang muslimah dalam mendekatkan diri kepada Allah. Selain itu bisa menunjukkan kesopanan dan kelembutan pemakainya. Penentuan status sosial, artikel ini juga melihat cara-cara yang digunakan oleh responden dalam mengatur tampilan jilbab dan pakaian yang dikenakannya. Hal ini dianggap penting, karena pada dasarnya status seseorang lebih dekat dengan gaya hidup (life style) orang tersebut (Narwoko \& Suyanto, 2004).

Perempuan berjilbab syar'i selain termotivasi untuk mematuhi syariat agama dan berusaha menjaga tingkah lakunya, juga ingin merubah penampilannya. Model baju yang dipakainya bukan gamis tetapi baju atasan dan bawahan sehingga lebih terkesan fashionable. Baginya meski jilbab yang dipakainya jilbab lebar (syar'i) tapi bisa tampil lebih modis karena kegiatannya menuntutnya demikian. Menarik untuk digarisbawahi, meskipun sama-sama berjilbab syar'i namun berbeda dalam tampilannya. Sampai pada fase ini, maka pengelompokan perempuan berjilbab, tidak secara otomatis menempatkan perempuan pada satu kategori berada pada status sosial yang sama. Jika dilihat pada uraian teoritis, ada kecenderungan masing-masing kelas mencoba mengembangkan gaya hidup yang eksklusif untuk membedakan dirinya dengan kelas yang lain.

Sedangkan perempuan yang mengawali berjilbab syar'i sebagai bentuk hijrahnya dari persoalan duniawi dan sebagai support untuk menjalani ajaran agama menjadi lebih baik. Selain itu ada misi dakwah yang dibangun dengan mengajak untuk menjalani agama menjadi lebih baik, tapi tidak bersifat memaksa. Ungkapan ini menunjukkan bahwa jilbab bisa dijadikan sebagai media untuk menunjukkan identitas pemakainya. Misi dakwah dibalik jilbab syar'i yang dipakainya seakan menegaskan komunitas yang diikutinya. Paparan pada perempuan berjilbab syar'i ini menunjukkan perbedaan cara 
perempuan berjilbab syar'i menunjukkan status sosialnya walaupun mereka ada pada kategori yang sama. Pertanyaan yang perlu diajukan di sini adalah apakah hal tersebut secara konsisten juga berlaku pada perempuan berjilbab pada kategori yang lain, dalam hal ini perempuan berjilbab sedang. Sebagaimana dua kategori perempuan berjilbab yang sudah diuraikan, perempuan berjilbab karena termotivasi ajaran agamanya. Menurutnya, jilbab sebagai atribut penting bagi seorang muslimah. Pilihan untuk berjilbab menunjukkan keserdahanaannya dalam berbusana baik dilihat dari model yang simpel atau harga yang dibayar untuk busananya dan yang diperhatikan adalah tidak berlebih-lebihan dan sudah memenuhi kriteria menutup aurat. Sehingga menjadi lebih leluasa untuk beraktifitas atau mengikuti kegiatan di lingkungannya tanpa ada dugaan mengikuti aliran tertentu.

Ada dua hal yang dapat dilihat dari perspektif hubungan memakai jilbab dengan status sosial. Pertama, baginya mempertahankan sikap kesederhanaan adalah cara terbaik untuk menyatakan eksistensinya dalam lingkungan sosial. Perspektif teori sosial, kesederhanaan adalah bagian dari gaya hidup. Dengan demikian, mempertahankan dan menampilkan kesederhanaan dalam berjilbab, bisa dimaknai sebagai cara untuk menentukan status sosialnya juga. Kedua, menghindari tuduhan terlibat pada aliran atau komunitas tertentu juga merupakan cara yang digunakan untuk menyatakan status sosial dirinya. Perspektif sosiologis, tindakan tersebut dikategorikan sebagai tuntutan atas penghargaan khusus atau sebuah tuntutan atas monopoli status yang khusus. Paparan tentang perempuan berjilbab sedang ini menunjukkan konsistensi pola perbedaan cara untuk menunjukkan status sosial. Sebagaimana perempuan berjilbab syar'i, perempuan berjilbab sedang juga memiliki cara yang berbeda-beda dalam mengaktualisasikan status sosialnya walaupun mereka ada pada kategori yang sama.

Pembahasan tentang status sosial perempuan berjilbab tetap mengikuti alur yang mengelompokkan perempuan berjilbab pada tiga kategori (bercadar, jilbab syar'i, dan jilbab sedang), namun faktanya menunjukkan bahwa masing-masing responden memiliki caranya sendiri dalam mengaktualisasikan status sosial. Konsekwensinya perempuan berjilbab yang berada dalam kategori yang sama tidak secara otomatis dapat dikategorikan dalam status sosial yang sama pula. Diferensiasi status sosial pada masing-masing responden, sesuai dengan teori sosial yang digunakan, lebih ditentukan 
oleh pemilihan model jilbab, kualitas dan harga bahan, tuntutan atas penghargaan khusus, panduan status sosial yang menempatkan batas pada apa yang dapat atau tidak dapat dilakukan, serta konsumsi barang dan gaya hidup eksklusif yang membedakan dirinya dari orang lain. Dengan demikian, kategorisasi perempuan berjilbab pada konteks ini hanya digunakan sebagai alat untuk melakukan sistematisasi pembahasan agar lebih mudah untuk dipahami.

\section{Dari Status Sosial ke Identitas Sosial: Sebuah Perspektif}

Status sosial dan identitas sosial sebenarnya berada pada sebuah pola yang hampir sama. Baik status sosial maupun identitas sosial sama-sama menjelaskan tentang relasi antara aktor dan sistem sosial yang sering disebut sebagai masyarakat. Hanya saja, jika status sosial lebih mengarah pada penentuan posisi dari masing-masing individu atau kelompok dalam komunitas masyarakat, maka identitas sosial lebih berbicara tentang generalisasi dan pembedaan individu atau kelompok dari individu atau kelompok lainnya. Bahkan, identitas sosial seringkali mendorong dilakukannya identifikasi dan pembedaan individu atau kelompok terhadap masyarakat yang lebih luas. Ketergabungan individu dalam kelompok dan mengikuti nilai-nilai yang ada dalam kelompok tersebut membentuk sebuah ikatan emosional yang menunjukkan ciriciri utama dari identitas sosial dirinya dan kelompoknya (Ritzer \& Goodman, 2004b).

Pada kasus perempuan berjilbab, aktualisasi status sosial tidak bisa dipotret dengan kategorisasi berjilbab dengan cadar, jilbab syar'i, dan jilbab sedang sebagaimana telah dijelaskan pada pembahasan sebelumnya. Berbeda dengan status sosial, dalam melakukan tinjauan tentang identitas sosial mereka, kategorisasi perempuan berjilbab yang secara konsisten digunakan sejak awal kajian ini menemukan relevansinya kembali. Para perempuan berjilbab bercadar misalnya, meskipun mereka berbeda-beda dalam mengaktualisasikan status sosialnya, akan tetapi mereka bisa diidentifikasi dengan satu identitas yang sama. Rata-rata perempuan berjilbab yang memakai cadar mengidentifikasi kelompoknya (ingroup) adalah komunitas yang mengikuti al-Quran dan sunnah yang berbeda dengan kelompok lain (outgroup). Demikian pula yang terjadi dengan perempuan berjilbab syar'i dan perempuan berjilbab sedang. Mereka samasama memandang dan mengidentifikasi dirinya dan kelompoknya sebagai komunitas yang berbeda dengan komunitas yang lain (Byrne, 2003, hal. 162). 
Pada tataran relasi antara masing-masing kategori perempuan berjilbab dengan kelompok di luarnya, dalam kajian sosiologis disebut sebagai intergroup, sebagaimana kasus di atas, maka keniscayaan munculnya dua hal tidak mungkin dihindarkan. Pertama, perilaku diskriminatif terhadap kelompok lain sebagai upaya untuk meningkatkan harga diri kelompok tersebut. Contoh pernyataan responden yang mengenakan jilbab syar'i, menganggap beberapa ritual ibadah kelompok lain sebagai sesuatu yang mengandung kesalahan. Dengan pernyataan ini, maka responden ingin menyatakan bahwa harga diri mereka jauh lebih tinggi dibandingkan kelompok lain karena mereka mengidentifikasi diri sebagai kelompok yang lebih benar dalam menjalankan syariat agama. Kedua, masing-masing individu yang tergabung dalam sebuah kategori akan berusaha meningkatkan harga dirinya sesuai dengan standar yang dimiliki oleh kelompoknya. Contoh yang bisa diajukan dalam kasus ini adalah pernyataan responden yang berjilbab sedang bahwa memakai jilbab tidak boleh melupakan sopan santun terhadap masyarakat di sekitarnya. Bagi perempuan berjilbab sedang, harga diri mereka harus disesuaikan dengan kelompoknya yang menghendaki nilai-nilai sopan santun dalam pergaulan menjadi salah satu identitas yang harus dipertahankan (J.C Turner, Michael, Penelope, D.R, \& Margaret, 1989, hal. 20).

Memahami perilaku perempuan berjilbab dalam menentukan harga dirinya, teori George Herbert Mead tentang konsep diri relevan digunakan di sini. Menurutnya, diri adalah kemampuan khas untuk menjadi subyek sekaligus obyek. Diri mengalami proses sosial berupa komunikasi antar manusia (Ritzer \& Douglas, 2009). Konsep diri ini menjadi penting bagi setiap individu karena empat alasan; pertama, ia adalah sumber utama kebaruan dalam proses sosial. Kedua, dengan diri, keberadaan individu menjadi bernilai penting. Ketiga, diri membentuk hal yang dicari-cari oleh setiap manusia (realisasi diri). Keempat, ia memungkinkan pengembangan "kepribadian yang ajeg” (Ritzer \& Douglas, 2009). Dalam kasus perempuan berjilbab, mereka (sebagai diri), memiliki kemampuan untuk menjadikan dirinya sebagai obyek dan memiliki kemampuan untuk membangkitkan respons dari orang lain. Respons terhadap jilbab yang dikenakannya inilah yang kemudian digunakan untuk mengidentifikasi identitas sosial mereka. 
Terlepas dari semua itu, hal penting yang perlu dilihat dalam pembahasan ini adalah tipe identitas sosial yang ingin ditunjukkan oleh masing-masing kategori perempuan berjilbab. Secara teoritis, identitas sosial dibagi menjadi dua yaitu; tipe aman dan tipe tidak aman. Sebuah identitas sosial masuk dalam tipe aman apabila masingmasing individu dalam sebuah kelompok memiliki kecenderungan untuk lebih mengutamakan melakukan evaluasi terhadap kelompok lain di luar dirinya (outgroup). Sedangkan tipe tidak aman adalah identitas sosial di mana individu-individu dalam sebuah kelompok lebih mengutamakan dalam melakukan evaluasi terhadap internal kelompoknya (ingroup) (Sarwono \& Eko, 2009, hal. 55).

Artikel ini menempatkan tiga kategori perempuan berjilbab di Ponorogo ke dalam tipe identitas sosial yang berbeda. Perempuan bercadar dan perempuan berjilbab syar'i memiliki kecenderungan masuk dalam tipe identitas sosial yang aman. Hal ini dapat dilihat dari kecenderungan mereka untuk mengoreksi kelompok-kelompok perempuan berjilbab di luar kelompok mereka sebagai kelompok yang kurang islami atau bahkan melakukan kesalahan dalam memahami perintah agama. Sementara kelompok perempuan berjilbab sedang lebih tepat jika dikategorikan ke dalam tipe identitas sosial yang tidak aman. Kelompok ini terlihat sangat sibuk untuk menata internal kelompoknya dalam hal membangun relasi dengan kelompok lain yang berada di luar dirinya.

\section{Simpulan}

Pola kehidupan keberagamaan (religiusitas) perempuan bercadar dan berjilbab syar'i cenderung mengarah pada eksklusivisme beragama. Sementara perempuan berjilbab sedang cenderung mengarah pada tipologi beragama yang inklusif-pluralis. Pilihan kelompok pertama untuk memakai cadar dan jilbab syar'i menyembunyikan makna eksklusivitas yang mengasumsikan bahwa menggunakan cadar atau memakai jilbab syar'i adalah pilihan hidup yang "paling sesuai" dengan ajaran agama. Sedangkan kelompok kedua lebih mengarah pada pandangan bahwa jilbab yang dikenakannya sesuai dengan kebenaran agama tanpa menafikan kemungkinan kebenaran lain yang ditemukan oleh perempuan yang memakai jilbab yang berbeda dari kelompoknya. 
Bagi perempuan bercadar dan berjilbab syar'i, memakai jilbab adalah identitas sosial yang dimensinya dibentuk oleh norma dan nilai-nilai agama "yang paling benar" yang harus ditaati dan dijalankan oleh setiap individu yang ada di dalam komunitas mereka. Sementara bagi perempuan berjilbab sedang, memakai jilbab adalah identitas sosial didasari oleh norma agama tanpa harus menafikan kebenaran ajaran agama yang dimiliki oleh kelompok lain dalam konteks relasi sosial dan hubungan kemasyarakatan.

Kesadaran atas identitas sosial (termasuk status sosial di dalamnya) tidak hanya ditentukan oleh satu aspek tertentu, memakai jilbab misalnya, perlu dibangun Bersama. Lebih dari itu, identitas sosial juga ditentukan oleh indikator-indikator lain yang dimiliki oleh seseorang atau kelompok dalam sebuah relasi sosial dengan orang atau kelompok lain. Oleh karena itu, perempuan berjilbab yang telah mengidentifikasi dan mengikatkan diri pada sebuah identitas sosial tertentu hendaknya juga memperhatikan aspek-aspek lain yang menjadi pembentuk identitas sosialnya itu. Identitas sosial hanyalah bagian kecil dari sebuah sistem sosial yang memiliki unsur-unsur yang sangat kompleks dan terhubung antara satu dengan yang lainnya. Oleh karena itu, maka perlu kajian lanjutan tentang perempuan berjilbab dalam ruang lingkup sosialnya yang lebih luas. 


\section{Referensi}

Ahmadi, D., \& Yohana, N. (2017). Konstruksi Jilbab sebagai Simbol Keislaman. Jurnal Mediator, $8(2)$.

Barnard, M. (2011). Fashion sebagai Komunikasi: Cara Mengomunikasikan Identitas Sosial, Seksual, Kelas, dan Gender, terj. Idy Subandy Ibrahim dan Yosal Iriantara. Yogyakarta: Jalasutra.

Basrowi, M., \& Soenyono. (2004). Teori Sosial dalam Tiga Paradigma. Surabaya: Yayasan Kampusina.

Blumer, H. (1969). Symbolic Interaction: Perspective and Method. New York: Printice Hall.

Bodovski, K. (2010). Parental Practices and Educational Achievement: Social Class, Race, and Habitus. British Journal of Sociology of Education, 31(2), 139-156.

Budiati, A. C. (2011). Jilbab: Gaya Hidup Baru Kaum Hawa. Jurnal Sosiologi Islam, 1(1), $59-70$.

Byrne, B. D. (2003). Psikologi Sosial edisi kesepuluh. Jakarta: PT. Gelora Aksara Pratama.

Farihah, I. (2018). Pementasan Agama Selebriti: Telaah Dramartugi Erving Goffman. YAQZHAN, 4(2), 219-241.

Fitriyah, A. (2018). Makna Tubuh bagi Mahasiswa Bercadar di Yogyakarta: Kajian Sosiologi Tubuh. Fikrah: Jurnal Studi Ilmu Aqidah dan Studi Keagamaan, 6(2), 241260.

Haryanto, D., \& Nugroho, G. E. (2011). Pengantar Sosiologi Dasar. Jakarta: Prestasi Pustakarya.

J.C Turner, Michael, A. ., Penelope, J. O., D.R, S., \& Margaret, S. . (1989). Rediscovering the Social Group: A Self Categorization Theory. New York: Basic Blackwell Hall.

Juneman. (2010). Psychology of Fashion: Fenomena Perempuan [Melepas Jilbab]. Yogyakarta: LKiS.

Mahmud, A. H. (1995). Haqiqat al- Hijab wa Hujjiyyat al-Hadith. Kairo: Maktabah Madbuly al-Shaghir.

Narwoko, D., \& Suyanto, B. (2004). Sosiologi teks pengantar dan terapan. Jakarta: Prenada Media.

Pakuna, H. B. (2014). Fenomena Komunitas Berjilbab; antara Ketaatan dan Fashion. Farabi, 11(1), 1-11. 
Poloma, M. M. (2010). Sosiologi Kontemporer: Interaksionisme Simbolik Perspektif: Manusia dan Makna, Terj. Tim Yasogama. Jakarta: Raja Grafindo Persada.

Rahayu, L. M. (2016). Budaya Pop dan Identitas Muslim di Indonesia Identitas. Ibda' Jurnal Kebudayaan Islam, 14(1), 139-155.

Rahayu, T., \& Fathonah, S. (2016). Tubuh dan Jibab: Antara Diri dan "Liyan." Jurnal AlA'raf, 13(2).

Ritzer, G., \& Douglas, J. (2009). Teori Sosiologi dari Teori Sosiologi Klasik sampai Perkembangan Mutakhir Teori Sosial Post-Modern. Yogyakarta: Kreasi Wacana.

Ritzer, G., \& Goodman, D. J. (2004a). Sosiologi Ilmu Pengetahuan Berparadigma Ganda, terj. Alimandan. Jakarta: Rajawali Press.

Ritzer, G., \& Goodman, D. J. (2004b). Teori Sosiologi Modern, terj. Alimandan. Jakarta: Prenada Media.

Sarwono, S. W., \& Eko, A. M. (2009). Psikologi Sosial. Jakarta: Salemba Humanika.

Setiawan, E. (2016). Fenomena Jilbab dalam Perspektif Sosiologi. Jurnal Dialogia, 14(1).

Shihab, M. Q. (2004). Jilbab, Pakaian Wanita Muslimah: Pandangan Ulama Masa Lalu \& Cendikiawan Kontemporer. Jakarta: Lentera Hati.

Suhendra, A. (2013). Kontestasi Identitas Melalui Pergeseran Interpretasi Hijab dan Jilbab dalam al-Qur'an. Jurnal Palastren, 6(1).

Thohari, C. (2011). Konstruksi Pemikiran Quraish Shihab tentang Hukum Jilbab Kajian Hermeneutika Kritis. Salam, 14(1), 75-91.

Wahib, A. (2015). Psikologi Agama Pengantar Memahami Perilaku Agama. Semarang: Karya Abadi Jaya.

Wahyuningsih, S. (2017). Perubahan Tatanan Hijab Mahasiswi Muslimah: Analisa Motif dan Ideologi Keislaman. Fikrah: Jurnal Studi Ilmu Aqidah dan Studi Keagamaan, 5(1), 75-98.

Yulikhah, S. (2016). Jilbab antara Kesalehan dan Fenomena Sosial. Jurnal Ilmu Dakwah, $36(1)$. 
Halaman ini bukan sengaja untuk dikosongkan 